\title{
Efektivitas Penambahan Natrium Diklofenak terhadap Larutan Obat Dilatasi Pupil pada Pasien Retinopati Diabetik
}

\author{
Arief S. Kartasasmita, Iwan Sovani, Bambang Setyohadji, Feti Karfiati, Andika Prahasta \\ Departemen Ilmu Kesehatan Mata Fakultas Kedokteran Universitas Padjadjaran \\ Pusat Mata Nasional Rumah Sakit Cicendo Bandung
}

\begin{abstract}
Abstrak
Pemeriksaan fundus memerlukan akses visualisasi yang baik. Pada penderita diabetes melitus, pupil sulit lebar menggunakan obat pelebar pupil standar sehingga perlu ditambahkan agen pelebar pupil. Penelitian ini dilakukan di Rumah Sakit Mata Cicendo periode Januari sampai Juli 2014 menggunakan metode double masked rendomized cotrolled trial terhadap 64 mata dari 32 subjek penelitian yang telah didiagnosis menderita retinopati diabetika dengan tingkat yang sama antara mata kiri dan kanan. Dibuat larutan kombinasi campuran 10 mL tropikamid 0,5\%/fenilefrin 0,5\%, $10 \mathrm{~mL}$ fenilefrin 5\% dan $10 \mathrm{ml} \mathrm{0,1 \%} \mathrm{Na} \mathrm{diklofenak} \mathrm{(larutan} \mathrm{I)} \mathrm{dan} \mathrm{campuran} 10 \mathrm{~mL}$ tropikamid 0,5\%/fenilefrin 0,5\%, dan $10 \mathrm{~mL}$ fenilefrin 5\% (larutan II). Setiap subjek mendapat salah satu larutan pada mata dan larutan yang lain pada sebelahnya secara acak. Dilakukan pemantauan dengan cara memotret pupil pada menit ke-15, 20, dan 25 pada kedua mata. Lebar pupil kedua kelompok perlakuan diukur dengan perangkat lunak khusus (image processing). Dari penenelitian terdapat perbedaan bermakna antara penggunaan larutan I dan larutan II dalam melebarkan pupil baik pada menit ke-15 ( $\mathrm{t}=2,02 ; \mathrm{p}=0,047)$, menit ke $20(\mathrm{t}=2,23$; $\mathrm{p}=0,029)$, dan pada menit ke-25 ( $\mathrm{t}=2,041 ; \mathrm{p}=0,045)$. Larutan kombinasi fenilefrin, tropikamid, dan natrium diklofenak menghasilkan efek dilatasi pupil yang lebih baik dibanding dengan larutan kombinasi fenilefrin dan tropikamid saja pada kasus retinopati diabetes. [MKB. 2017;49(3):199-207]
\end{abstract}

Kata kunci: Dilatasi pupil, natrium diklofenak, retinopati diabetika

\section{Effectiveness of Sodium Diclofenac Addition to Pupil Dilatation Agent on Diabetic Retinopathy Patients}

\begin{abstract}
Fundus examination requires good visualization of fundus. In diabetic patients, it is difficult for the pupil to dilate using the standard pupilarry dilating agent. To achieve proper dilation, special agents have to be added to the standard dilation agent. The study was conducted in Cicendo Eye Hospital from January to July 2014, using double masked randomized controlled trial to 32 patients (64 eyes) who were diagnosed as suffering from diabetic retinopathy with the same grade on both eyes. Eye drop solutions were developed beforehand by mixing $10 \mathrm{~mL}$ of $0.5 \%$ tropicamide $/ 0.5 \%$ phenylephrine, $10 \mathrm{~mL}$ of $5 \%$ phenylephrine, and $10 \mathrm{~mL}$ of $0.1 \%$ diclofenac-natrium (solution I) and also by mixing $10 \mathrm{~mL}$ of $0.5 \%$ tropicamide $/ 0.5 \%$ phenylephrine and $10 \mathrm{~mL}$ of $5 \%$ phenylephrine (solution II). Every subject received one drop of one solution on one eye and the other solution on the other eye in randomly fashion. The observation was performed by taking photographs of the pupil on both eyes 15 , 20, and 25 minutes of observation. The resulting pupil photographs were then analyzed and measured using special image processing software and compared. It was revealed that there were statistical differences in pupil dilation between solution I and solution II at 15 minutes $(\mathrm{t}=2.02 ; \mathrm{p}=0.047), 20$ minutes $(\mathrm{t}=2.23, \mathrm{p}=0.029)$, and 25 minutes $(t=2.041, p=0.045)$. Phenilefrine, tropicamide and diclofenac-natrium combination solution provides better dilation effect on the pupil compared to the combination of phenilefrine and tropicamide alone in diabetic retinopathy patient. [MKB. 2017;49(3):199-207]
\end{abstract}

Key words: Diabetic retinopathy, natrium diclofenac, pupil dilatation

Korespondensi: Arief S. Kartasasmita, dr., Sp M(K), M.Kes, Ph.D., Departemen Ilmu Kesehatan Mata Fakultas Kedokteran Universitas Padjadjaran/Pusat Mata Nasional Rumah Sakit Cicendo Bandung, E-mail: a.kartasasmita@unpad.ac.id 


\section{Pendahuluan}

Retinopati diabetika adalah penyakit mata yang menyebabkan kebutaan cukup tinggi di dunia. Insidensi retinopati diabetika di dunia adalah $1,5 \%$ sementara kebutaan yang diakibatkan oleh retinopati diabetika mencapai angka $1,2 \% 0^{1,2}$

Insidensi diabetes melitus di dunia cenderung meningkat sehingga tindakan pada pencegahan dan penanganan retinopati diabetika menjadi sangat penting. Berbagai cara dilakukan untuk mencegah kebutaan akibat retinopati diabetika, di antaranya pencegahan menggunakan metode penapisan yang adekuat, pengobatan retinopati diabetika dengan terapi laser pada keadaan dini, dan metode diagnostik lain dengan bantuan alat seperti angiorafi fundus floresin. ${ }^{3,4}$

Seluruh metode untuk penanganan retinopati diabetika tersebut juga membutuhkan akses visualisasi yang baik terhadap keadaan fundus sehingga pupil yang cukup lebar memberikan ruang yang cukup untuk aksesibilitas visualisasi fundus tersebut. Selama ini keadaan tersebut dimungkinkan dengan cara melebarkan pupil menggunakan obat-obatan midriatikum. Namun, dikarenakan pada keadaan retinopati diabetika sering ditemukan keadaan neuropati autonomik diabetika, maka pupil penderita diabetes melitus sering sulit lebar. ${ }^{4,5}$ Oleh karena itu, konsentrasi obat midriatikum yang diberikan harus lebih tinggi dibanding dengan orang tanpa diabetes untuk mencapai efek midriatikum yang sama. Di samping itu, dikarenakan epitel kornea itu mempunyai efek sawar terhadap seluruh obat yang diteteskan maka konsentrasi obat yang mencapai struktur di dalam bola mata akan berkurang. Dengan alasan tersebut, pemeriksa sering kali harus memberikan obat-obatan midriatikum berulang-ulang agar konsentrasi obat yang dapat menembus epitel kornea lebih tinggi sehingga pupil pada penderita retinopati diabetika dapat melebar sesuai yang diinginkan. Pemberian obat yang berulang-ulang ini, di samping membutuhkan waktu yang lama dan apabila dilakukan dalam waktu yang cepat akan menyebabkan edema kornea sehingga malah akan memperburuk visualisasi pemeriksa. ${ }^{6}$

Selama ini para ahli telah merekomendasikan penggunaan kombinasi tropikamid dan efinefrin untuk melebarkan pupil.7.8 Namun, kombinasi kedua obat ini kadang dirasakan kurang efektif pada pasien retinopati diabetika akibat keadaan neuropati yang juga terjadi. Oleh karena itu, perlu dicari obat tambahan yang dapat membantu penetrasi obat sehingga efek midriasis akan lebih mudah dicapai.
Kortikosteroid dan obat anti-inflamasi nonsteroid diketahui memiliki efek penetrasi kornea yang baik. Namun, kortikosteroid memiliki efek negatif seperti glaukoma, peningkatan untuk terjadinya infeksi, dan lain-lain sehingga telah dilaporkan untuk dapat mencampur obat-obatan midriatikum dengan obat anti-inflamasi nonsteroid dengan tujuan memperbaiki penetrasi obat midriatikum tersebut sebagai obat dilatasi pupil pada operasi katarak dengan hasil yang baik. $^{9}$

Melihat hasil yang baik pada kombinasi obat tersebut, mengingat saat ini belum ditemukan obat khusus yang digunakan untuk melebarkan pupil pada kasus retinopati diabetika maka perlu diteliti apakah kombinasi obat tersebut dapat membantu pelebaran pupil pada kasus retinopati diabetika apabila dibanding dengan obat-obatan standar yang selama ini digunakan sehubungan dengan pentingnya deteksi dini kasus retinopati diabetika untuk mencegah keadaan yang lebih berat.

Walaupun keadaan neuropati otonom akibat diabetes yang diderita tidak diperbaiki dengan penambahan kombinasi obat tersebut, namun dengan penetrasi yang lebih baik diharapkan konsentrasi obat di dalam struktur mata akan lebih tinggi sehingga proses pendilatasian pupil akan menjadi lebih cepat dan lebih baik

Penelitian ini akan menilai efek penambahan obat anti-inflamasi non-steroid pada rejimen obat midriatikum yang saat ini dipergunakan terhadap pasien retinopati diabetika dalam upaya melebarkan pupil.

\section{Metode}

Dilakukan double masked randomized controlled trial untuk melihat efek penambahan natrium diklofenak tetes terhadap kombinasi fenilefrin dan juga tropikamid dalam mendilatasi pupil pada penderita retinopati diabetika. Setelah mendapat persetujuan Komisi Etik Penelitian Kesehatan FK Unpad No. 74/FKUP-RSHS/KEPK/ $\mathrm{KEP} / \mathrm{EC} / 2006$, subjek penelitian dipilih dengan kriteria inklusi penderita retinopati diabetes dan memiliki ukuran pupil saat miosis 2-4 $\mathrm{mm}$. Kriteria eksklusi yang diambil adalah kelainan anatomi kornea dan iris, pasien dengan kontra indikasi penggunaan midriatikum, natrium diklofenak dan fenilefrin; pasien dengan tekanan intraokular tinggi diatas $20 \mathrm{mmHg}$ dan pasien dengan relatively afferent pupillary defect dan afferent pupillary defect. Penarikan sampel dilakukan secara acak dengan blok permutasi 
(permutation block random sampling) terhadap pasien-pasien yang datang ke Unit Vitreoretina Rumah Sakit Mata Cicendo pada bulan JanuariJuli tahun 2014 yang telah terdiagnosis sebagai retinopati diabetika. Apabila satu mata pasien yang mendapat perlakuan, maka diambil mata sebelahnya pada pasien yang sama sebagai kontrol. Variabel penelitian yang dinilai adalah variabel skala rasio yang merupakan ukuran diameter pupil yang diukur berdasar satuan mili meter dengan tingkat ketelitian sampai 0,1 milimeter.

Untuk menilai efektivitas penambahan obat anti-inflamasi non-steroid, ditambahkan obat natrium diklofenak terhadap larutan standar sehingga didapatkan larutan obat I sebagai obat perlakuan adalah larutan obat yang didapatkan dengan mencampurkan $10 \mathrm{~mL}$ tropikamid 0,5\%/ fenilefrin 0,5\%, $10 \mathrm{~mL}$ fenilefrin $5 \%$ dan $10 \mathrm{ml}$ $0,1 \%$ na diklofenak, sesuai yang dikemukakan Hirowatari dkk. ${ }^{10}$ Sementara larutan obat II sebagai obat kontrol adalah larutan obat yang didapatkan dengan mencampurkan $10 \mathrm{~mL}$ tropikamid 0,5\%/fenilefrin $0,5 \%$, dan $10 \mathrm{~mL}$ fenilefrin $5 \%$ yang selama ini dipakai sebagai obat standar midriatikum pada pasien diabetes. Pencampuran obat dilakukan secara steril dan mengikuti standar kualitas pada penyiapan obat. Ukuran pupil pada penelitian ini didefinisikan sebagai ukuran panjang vertikal dari tepi sentral pupil bagian lateral sampai dengan bagian medial yang diukur dengan komputer secara digital dan dinyatakan dalam milimeter.

Setelah informed consent didapatkan maka subjek penelitian diperiksa untuk menentukan kriteria inklusi dan eksklusi. Kemudian, pasien diberikan pemberian campuran obat I pada mata penderita dan campuran obat II pada mata sebelahnya secara tersamar berdasar atas randomisasi. Setelah menunggu sampai durasi aksi obat tercapai, pupil kemudian difoto dengan menggunakan kamera digital yang terdapat pada lampu celah (slit lamp) sebanyak 3 kali untuk mendapatkan hasil terbaik, dengan tingkat iluminasi pada lampu celah diatur pada tingkat kekuatan 50\%. Diameter pupil yang diambil adalah diameter vertikal.

Pemantauan efek obat dilakukan dengan mengukur lebar pupil mata kanan dan kiri pada waktu 15 menit, 20 menit, dan 25 menit setelah pemberian obat. Keadaan ini sesuai dengan teori bahwa kadar tertinggi larutan fenilefrin dan tropikamid tercapai pada 20 menit pertama, dan mulai meningkat pada 15 menit pertama. ${ }^{11}$

Setelah pemotretan lengkap, pengukuran dilakukan menggunakan perangkat lunak Adobe
Photoshop secara tersamar. Hasil pengukuran kemudian didokumentasikan. Hasil penilaian kemudian dicatat dan dianalisis menggunakan statistik. parametrik memakai metode paired t-test. Kemaknaan itu dilihat berdasar atas nilai $\mathrm{p}<0,05$.

\section{Hasil}

Didapatkan 64 mata dari 32 pasien yang telah memenuhi kriteria inklusi dan tidak termasuk eksklusi dan bersedia untuk menjadi subjek penelitian di Unit Vitreoretina RS Mata Cicendo. Setiap pasien telah diteteskan obat I pada satu mata dan obat II pada mata yang lain secara acak dan tersamar. Hasil penelitian didokumentasikan untuk dianalisis melalui perangkat lunak khusus sehingga didapatkan ukuran pupil seluruh pasien.

\section{Tabel 1 Karakteristik Seluruh Pasien} Penelitian

\begin{tabular}{|c|c|}
\hline Karakteristik Pasien & \\
\hline \multicolumn{2}{|l|}{ Usia (tahun) } \\
\hline Rata-rata & 57,21 \\
\hline Simpangan baku & 9,32 \\
\hline Minimum & 36 \\
\hline Maksimum & 75 \\
\hline \multicolumn{2}{|l|}{ Jenis kelamin $(n=32)$} \\
\hline Laki-laki & 13 \\
\hline Perempuan & 19 \\
\hline \multicolumn{2}{|l|}{ Visus mata dasar (tanpa koreksi) } \\
\hline Rata-rata (logMar) & 0.8 \\
\hline Simpangan baku (logMar) & 0,46 \\
\hline Minimum (Logmar) & 1,76 \\
\hline Maksimum (LogMar) & 0.0 \\
\hline \multicolumn{2}{|l|}{ Larutan I } \\
\hline Mata kanan & 15 \\
\hline Mata kiri & 17 \\
\hline \multicolumn{2}{|l|}{ Larutan II } \\
\hline Mata kanan & 15 \\
\hline Mata kiri & 17 \\
\hline \multicolumn{2}{|l|}{ Diagnosis } \\
\hline $\begin{array}{l}\text { Non proliverative diabetic } \\
\text { Retinopathy (NPDR) }\end{array}$ & 22 \\
\hline $\begin{array}{l}\text { Proliverative diabetic } \\
\text { Retinopathy (PDR) }\end{array}$ & 10 \\
\hline
\end{tabular}


Arief S. K.: Efektivitas Penambahan Natrium Diklofenak terhadap Larutan Obat Dilatasi Pupil pada Pasen Retinopati Diabetik

Tabel 2 Perbandingan Ukuran Pupil antara Pemberian Larutan I dan Larutan II pada Waktu 15 Menit, 20 Menit, dan 25 Menit

\begin{tabular}{lcccccc}
\hline & \multicolumn{2}{c}{15 Menit } & \multicolumn{2}{c}{20 Menit } & \multicolumn{2}{c}{ 25 Menit } \\
\hline Larutan obat & Larutan I & Larutan II & Larutan I & Larutan II & Larutan I & Larutan II \\
Rerata ukuran pupil(mm) & 72,07 & 64,88 & 82,59 & 76,50 & 88,98 & 84,91 \\
Simpangan baku (mm) & 14,44 & 14,03 & 11,25 & 10,60 & 8,44 & 8,66 \\
Ukuran terkecil (mm) & 38,7 & 34,6 & 54,60 & 52,10 & 68,4 & 66,0 \\
Ukuran terbesar (mm) & 93,8 & 91,7 & 99,10 & 94,90 & 101,2 & 100,9 \\
\hline
\end{tabular}

Keterangan: 15 menit $(\mathrm{t}=2.02 ; \mathrm{p}=0.047) ; 20$ menit $(\mathrm{t}=2.23 ; \mathrm{p}=0.029)$, dan 25 menit $(\mathrm{t}=2.041 ; \mathrm{p}=0.045)$

Dari Tabel 1 terlihat bahwa usia rata-rata pasien penelitian adalah 57,21 tahun dengan jenis kelamin paling banyak adalah perempuan. Visus dasar rata-rata dari seluruh mata pasien adalah 0,8 logMar dengan rentang 1,76 logMar sampai 0,0 LogMar.

Diagnosis retinopati diabetika yang paling banyak ditemukan adalah retinopati diabetes non-proliferatif (non-proliverative diabetic retinopathy/NPDR) dengan perbandingan kasus NPDR dengan retinopati diabetika proliferatif (proliverative diabetic retinopathy/PDR) adalah 0,45 . Lamanya waktu sejak pasien menderita diabetes melitus sampai terdiagnosis retinopati diabetes tidak diketahui dengan jelas karena hampir seluruh pasien tidak mempunyai catatan yang akurat mengenai waktu awal menderita penyakit diabetes melitus. Walaupun tidak ada data yang akurat, seluruh pasien mengaku memeriksakan penyakit diabetes melitus yang diderita secara teratur kepada dokter.
Terlihat dari Tabel 2 bahwa pada 15 menit pertama ukuran pupil rata-rata pada larutan I memberikan kenaikan $240 \%$ dibandingkan dengan rata-rata pupil normal $(3 \mathrm{~mm})$. Sementara ukuran pupil rata-rata larutan II memberikan kenaikan ukuran pupil 216\% dibanding ukuran normal. Secara sekilas, hal ini sesuai dengan penilitian Hirowatari dkk, ${ }^{10}$ bahwa larutan I yang memiliki kandungan Na diklofenak memberikan efek dilatasi yang lebih lebar. Secara individu perbedaan ukuran pupil pada setiap pasien terlihat pada Gambar 1

Tampak pada Gambar 1 secara umum larutan I konsisten menghasilkan ukuran pupil yang lebih lebar jika dibanding dengan Larutan II. Pada beberapa subjek terlihat perbedaan ukuran tampak tidak berbeda atau sama. (garis putus : larutan I; garis lurus : larutan II)

Terlihat dari Tabel 2 bahwa pada 20 menit pertama ukuran pupil rata-rata pada larutan I memberikan kenaikan $114 \%$ dibanding dengan

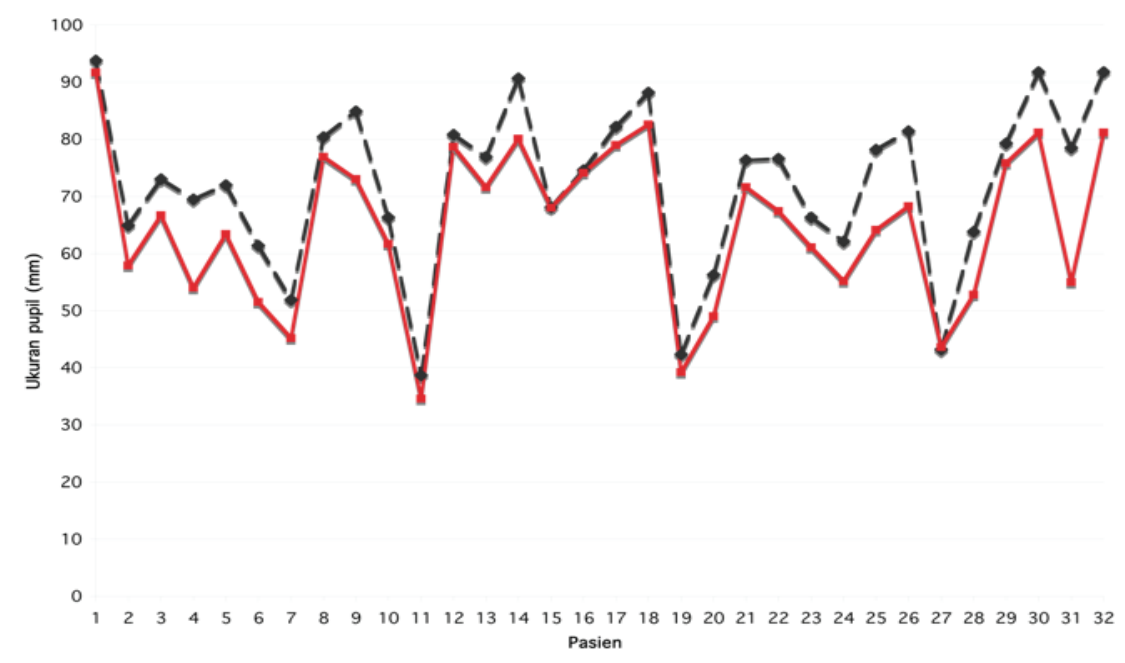

Gambar 1 Perbedaan Ukuran Pupil Tiap-tiap Pasien terhadap larutan I dan II pada Waktu 15 Menit 


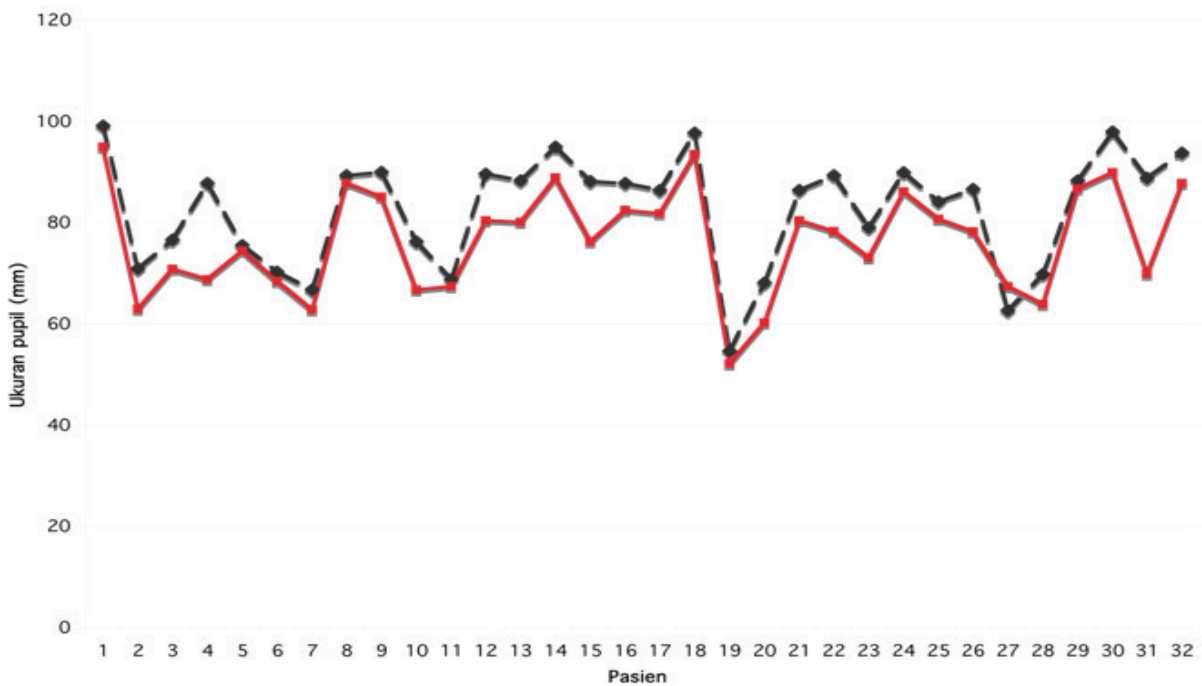

Gambar 2 Perbedaan Ukuran Pupil Tiap-tiap Pasien terhadap Larutan I dan II pada Waktu 20 Menit

pupil rata-rata pada pemeriksaan sebelumnya. Sementara rata-rata ukuran pupil larutan II memberikan kenaikan ukuran pupil $117 \%$ bila dibanding dengan ukuran sebelumnya. Secara sekilas, tidak terlihat perbedaan kenaikan ukuran pupil dibandingkan sebelumnya di antara larutan kandungan Na diklofenak dan larutan kontrol. Hal ini juga berbeda dengan yang dikemukanan oleh Hirowatari dkk..$^{10}$ yang menyatakan bahwa kenaikan ukuran pupil terus bertambah seiiring dengan waktu jika dibanding dengan larutan kontrol. Keadaan ini kemungkinan dikarenakan pada waktu 20 menit, konsentrasi obat larutan
I sudah cukup tinggi sehingga kenaikan ukuran pupil tidak terlalu besar dibanding dengan obat larutan II seperti pada saat 15 menit pertama. Secara individu perbedaan ukuran pupil pada setiap pasien terlihat pada Gambar 2.

Tampak pada Gambar 2 secara umum larutan I konsisten menghasilkan ukuran pupil yang lebih lebar jika dibanding dengan Larutan II. Pada beberapa subjek terlihat perbedaan ukuran tampak tidak berbeda atau sama. (garis putus : larutan I; garis lurus : larutan II)

Terlihat dari Tabel 2 bahwa pada 20 menit pertama ukuran pupil rata-rata pada larutan

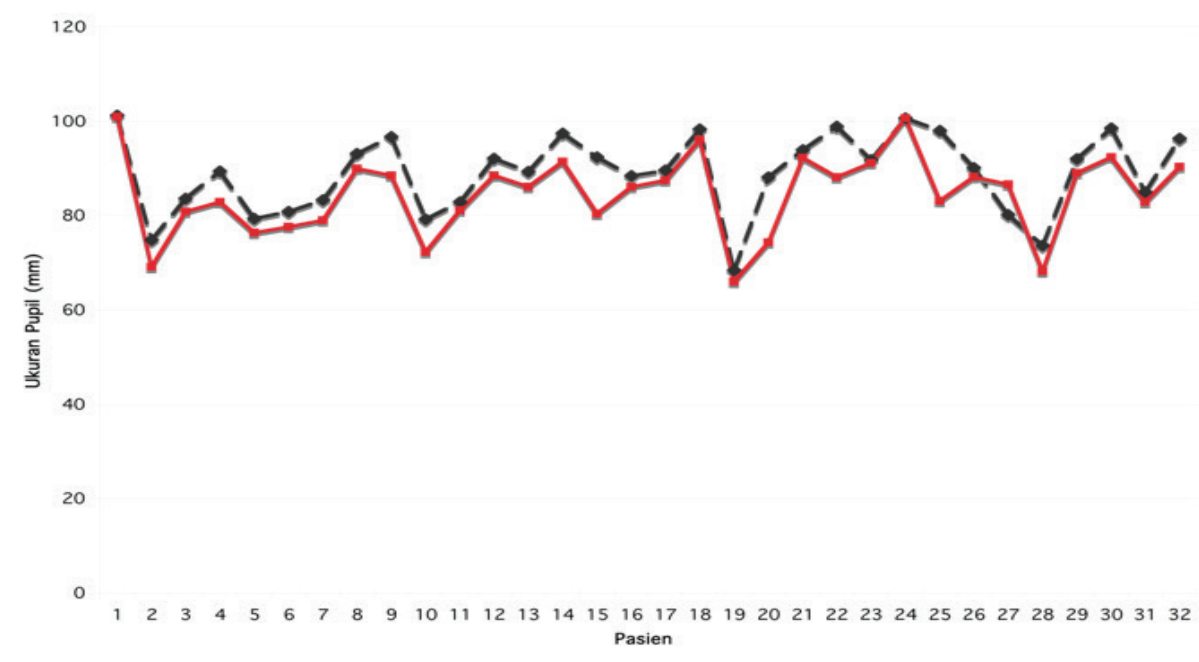

Gambar 3 Perbedaan Ukuran Pupil Tiap-tiap Pasien terhadap Larutan I dan II pada Waktu 25 Menit 
I memberikan kenaikan 107,7\% dibanding dengan pupil rata-rata pemeriksaan sebelumnya. Sementara rata-rata ukuran pupil larutan II memberikan kenaikan ukuran pupil 110,6\% dibanding dengan ukuran sebelumnya. Secara sekilas seperti halnya pada menit ke 20 , larutan I memiliki prosentase kenaikan ukuran pupil rata-rata lebih kecil dibanding dengan larutan I walaupun ukuran rerata pupil mata yang mendapatkan larutan I lebih besar dibandingkan larutan II. Hal ini kemungkinan disebabkan pada jangka panjang, lambat laun konsentrasi obat larutan II dalam mata akan terus meningkat, sementara larutan I konsentrasi obat pada 15 menit pertama sudah cukup tinggi sehingga kenaikan konsentrasinya tidak begitu tinggi lagi pada menit-menit berikutnya. Secara individu perbedaan ukuran pupil pada waktu 25 menit tampak pada Gambar 3.

Tampak pada Gambar 3 secara umum larutan I konsisten menghasilkan ukuran pupil yang lebih lebar jika dibandingkan dengan larutan II. Pada beberapa subjek, terlihat perbedaan ukuran tampak tidak berbeda atau sama. (garis putus : larutan I; garis lurus : larutan II).

Seluruh subjek penelitian, baik pada menit 15, 20, dan 25 memberikan ukuran pupil yang lebih besar pada larutan I dibanding dengan pada larutan II secara konsisten, kecuali pada subjek nomor 28 yang memberikan hasil kebalikannya. Hal ini juga sesuai dengan penelitian Hirowatari $\mathrm{dkk}^{10}$ yang memperlihatkan penambahan $\mathrm{Na}$ diklofenak akan memberikan dilatasi pupil yang lebih baik pada kasus retinopati diabetik. Pada subjek nomor 28, larutan II memberikan ukuran pupil yang lebih lebar dibanding dengan larutan I secara konsisten pada menit 15, 20, dan 25. Keadaan ini kemungkinan disebabkan oleh respon yang tidak adekuat terhadap natrium diklofenak, ${ }^{13}$ atau pada mata yang mendapatkan larutan I memiliki neuropati autonomik diabetes yang lebih besar dibanding dengan mata yang mendapatkan larutan II sehingga ukuran pupil lebih sulit melebar pada mata yang diberikan larutan I. Secara medis terlihat bahwa pada waktu 25 menit terdapat perbedaan ukuran pupil yang bermakna antara pemberian larutan I dan larutan II pada retinopati diabetika.

\section{Pembahasan}

Otot dilator pupil berada di seluruh stroma iris kecuali di daerah pupil. Setiap selnya bergabung satu dengan yang lain oleh desmosom multipel dan dapat berkontraksi sebagai suatu kesatuan.
Otot spingter pupil membentuk lingkaran yang mengelilingi pupil dan terpisah dari lapisan neuroepitelial di posteriornya. Secara histologis, otot ini dibentuk dari serabut otot polos yang berhubungan dengan stroma iris dan otot dilator pupil. 8

Pada keadaan normal, pupil akan bereaksi terhadap intensitas cahaya. Pupil akan berdilatasi dan konstriksi sebagai reaksi dari perubahan intensitas cahaya yang akan dapat merangsang sistem simpatetik dan parasimpatetik dari pupil. Dilatasi pupil merupakan bagian dari pemeriksaan rutin mata. Keadaan pupil yang berdilatasi sangatlah diperlukan untuk menilai keadaan mata, terutama segmen posterior mata tersebut. 5

Otot spingter iris ini mempunyai reseptor muskarinik terhadap asetilkolin. Reseptorreseptor ini tidak secara langsung berhubungan dengan channel ion antarmembran namun juga terhadap sekelompok reaksi yang bertingkat dari fosforilasi yang menyebabkan messenger sekunder intraokular lepas sehingga pada akhirnya akan menyebabkan otot berkontraksi. ${ }^{14}$ Proses ini membutuhkan cukup waktu sehingga menghasilkan apa yang kita kenal sebagai waktu laten reflek pupil. Agen yang bersifat agonis terhadap reseptor ini memiliki efek konstriksi pupil, termasuk di antaranya karbakol dan pilokarpin. ${ }^{15}$ Apabila terjadi denervasi otot akibat lesi baik preganglion maupun posganglion akan berakibat pada hipersensitivitas pupil terhadap muskarinik agonis.

Antagonis terhadap reseptor ini (anti muskarinik) dipergunakan untuk mendilatasi pupil pada kepentingan klinis atau untuk mencapai keadaan siklopegik pada kepentingan pemeriksaan refraksi. Termasuk ke dalam obat golongan ini adalah tropikamid, siklopentolat, homatropin, dan juga atropin. Otot dilator iris mempunyai reseptor alfa-adrenegik terhadap noradrenalin. Noradrenalin tersebut disintesis dan disimpan pada pre-junction akhir saraf simpatetik. Pemberian hidroksiamfetamin 1\% secara topikal dapat menyebabkan noradrenalin yang tersimpan terlepas dan dapat menyebabkan pupil pada penderita normal akan berdilatasi. Sekali dilepaskan maka noradrenalin yang aktif secara prinsip akan dinonaktifkan oleh proses pengambilan kembali. Pemberian kokain tetes $4 \%$ akan menghentikan proses pengambilan kembali ini sehingga meningkatkan konsentrasi noradrenalin sehingga menyebabkan midriasis pada mata normal. Hanya fenilefrin obat yang merupakan agonis murni pada reseptor tersebut yang digunakan pada aplikasi klinis. ${ }^{9}$ 
Kombinasi tropikamid $1 \%$ dan fenilefrin $10 \%$ telah terbukti efektif untuk prosedur pemeriksaan mata yang membutuhkan dilatasi pupil. Fenilefrin bekerja dengan memaksimalkan stimulasi terhadap otot dilator pupil sementara tropikamid melumpuhkan konstriktor pupil. Kedua obat ini bekerja secara sinergis. ${ }^{7}$

Tropikamid ialah obat parasimpatolitik yang memiliki aksi cepat yang menghasilkan efek siklopegik dan midriasil dengan durasi yang pendek. Tropikamid tidak berikatan dengan jaringan sekuat atropin. Efek midriasil maksimal tropikamid dicapai dalam waktu 30 menit dan menghilang secara total dalam waktu 6 jam. Tropikamid memiliki efek midriasil yang lebih besar daripada efek siklopegiknya. ${ }^{7}$

Fenilefrin merupakan obat simpatomimetik juga sering dipakai untuk melebarkan pupil dalam pemeriksaan oftalmoskop. Efek maksimal didapatkan dalam jangka waktu 20 menit dan menghilang dalam jangka waktu 2 jam. Efek midriasil dari fenilefrin sedikit lebih kecil daripada yang dihasilkan oleh obat-obatan siklopegik. Walaupun mempergunakan fenilefrin dirasa cukup untuk melebarkan pupil, tetapi karena efek midriasil fenilefrin tidak tahan terhadap rangsang cahaya maka obat tersebut sering digunakan bersama-sama dengan obat siklopegik dalam upaya mencegah respons miosis terhadap pencahayaan. Membuat kedua obat ini menjadi larut dalam lemak dengan cara mencampurkannya dengan larutan $\mathrm{pH}$ tinggi akan meningkatkan penetrasi obat tersebut 6 kali lipat lebih tinggi dikarenakan lebih mudah untuk menembus sawar kornea. ${ }^{13}$

Neuropati autonomik diabetes merupakan kompikasi yang sering dan paling menyulitkan pada keadaan diabetes melitus. ${ }^{16}$ Walaupun komplikasi ini hanya terjadi pada seluruh tubuh, tetapi kadang hanya ditemui pada satu organ. Faktor yang berpengaruh pada komplikasi ini adalah gangguan pada metabolisme, insufisiensi vaskular, faktor pertumbuhan hilang dan juga destruksi autoimun pada serabut saraf. ${ }^{16}$

Aktivasi jalur poliol akibat dari kondisi hiperglikemik yang menyebabkan akumulasi sorbitol dan juga perubahan potensial pada perbandingan NAD:NADH dapat menyebabkan kerusakan langsung serabut saraf perifer dan dapat menurunkan aliran darah menuju serabut saraf. Hal ini akan meningkatkan stres oksidatif dengan peningkatan produksi radikal bebas akan menghasilkan kerusakan endotel vaskular dan menurunkan ketersediaan nitrit oksida. Keadaan ini akan menghasilkan pembentukan peroksinitrit dan kerusakan endotel dan neron, sebuah proses yang lebih dikenal sebagai stres nitrostatif. ${ }^{17}$

Pada keadaan retinopati diabetika sering terjadi neuropati pada saraf autonom yang membuat kelumpuhan otot dilator pupil. Keadaan neuropati pada saraf autonom pupil pada kasus retinopati diabetika tidak tergantung pada tingkat keparahan retinopati diabetikanya, namun lebih ditentukan oleh lamanya penderita memiliki kelainan diabetes melitus. ${ }^{18}$ Pada keadaan ini pupil mata sulit lebar meskipun mempergunakan obat-obatan dilatasi pupil sehingga pada keadaan ini diperlukan upaya lebih untuk melebarkan pupil. ${ }^{8}$

Epitel kornea mempunyai sawar yang paling kuat terhadap masuknya obat secara topikal. Pertama, sel epitel diikat oleh desmosom di antara batas lateral sel superfisial. Kedua, epitel kornea merupakan sel hidrofobik (seperti membran sel) sehingga obat-obat yang larut dalam lemak dapat melaluinya. Sebagai tambahan, membran Bowman yang berupa lembaran kolagen aselular (dengan ketebalan 10-um) dan terletak antara membrana basalis epitel dan stroma kornea, berfungsi sebagai sawar terhadap penetrasi obat. Sebaliknya, stroma yang membentuk $90 \%$ substansi kornea dan substansi di sekitarnya (glikosaminoglikan dan air) menyebabkan obat yang larut dalam air tidak terionisasi dapat melalui kornea lebih mudah dibanding dengan obat yang larut dalam lemak. Akhirnya, transpor yang melalui epitel kornea relatif bebas karena terdapat gap junction yang menyebabkan penetrasi yang baik bagi kebanyakan obat ke dalam humor akuos. Banyak obat mata topikal merupakan basa lemah, sebagai contoh tropikamid, siklopentolat, dan atropin. Obat-obat ini bisa berupa bentuk terionisasi atau tidak terionisasi dengan rentang $\mathrm{pH}$ lapisan air mata ( $\mathrm{pH} 7,4)$. Meninggikan $\mathrm{pH}$ larutan obat akan meningkatkan penetrasi kornea dan juga absorbsi sistemik. Koefisien partisi (rasio konsentrasi dalam dua bagian kompartemen kornea dan stroma) mampu ditinggikan dengan cara meninggikan $\mathrm{pH}$ saat fase air yang menghasilkan obat tidak terionisasi dan membuat obat tersebut menjadi lebih larut dalam lemak. ${ }^{19}$

Obat anti-inflamasi non-steroid selama ini dipergunakan sebagai obat yang efektif dalam mengobati peradangan dengan cara penghambat sintesis prostaglandin baik dalam jalur sikooksigenasi atau lipo-oksigenasi. Salah satu obat dari golongan ini adalah natrium diklofenak, yang terdapat untuk sediaan mata dengan konsentrasi $0,1 \%$. Na diklofenak ini memiliki pH 
bufer sekitar 7,2. ${ }^{20}$ Dari penelitian Hirowatari $\mathrm{dkk}^{10}$ telah terbukti bahwa dengan mencampur larutan natrium diklofenak dengan tropikamid dan fenilefrin akan memperbaiki penetrasi larutan tropikamid dan fenilefrin melalui kornea.

Dari penelitian ini dapat disimpulkan bahwa penambahan natrium diklofenak menyebabkan suasana basa pada epitel kornea sehingga dapat memperbaiki penetrasi obat dan memperbaiki efek midriasis pada pasien retinopati diabetika.

\section{Daftar Pustaka}

1. Lin JC, Shau WY, Lai MS. Sex- and age-specific prevalence and incidence rates of sightthreatening diabetic retinopathy in Taiwan. JAMA Ophthalmol. 2014;132(8):922-8.

2. Xu J, Xu L, Wang YX, You QS, Jonas JB, Wei WB. Ten-year cumulative incidence of diabetic retinopathy. The Beijing Eye Study 2001/2011. PLoS One. 2014;9(10):e111320.

3. Lee DJ, Kumar N, Feuer WJ, Chou CF, Rosa PR, Schiffman JC, dkk. Dilated eye examination screening guideline compliance among patients with diabetes without a diabetic retinopathy diagnosis: the role of geographic access. BMJ Open Diabetes Res Care. 2014; 2(1):e000031.

4. Rim TH, Byun IH, Kim HS, Lee SY, Yoon JS. Factors associated with diabetic retinopathy and nephropathy screening in Korea: the Third and Fourth Korea National Health and Nutrition Examination Survey (KNHANES III and IV). J Korean Med Sci. 2013;28(6):81420.

5. Preti RC, Motta AA, Maia 00, Jr., Morita C, Nascimento VP, Monteiro ML, dkk. Relationship between diabetic retinopathy severity and the timespan between the endocrinopathy diagnosis and the first ophthalmic examination. Arq Bras Oftalmol. 2010;73(3):240-3.

6. McCannel CA. Improved intraoperative fundus visualization in corneal edema: the viscoat trick. Retina. 2012;32(1):189-90.

7. Punyawattanaporn A, Tengtrisorn S, Sangsupawanich P. Pupil dilatation after single and triple doses of mydriatic agent in preterm infants. J Med Assoc Thai. 2009;92(11):1458-62.

8. Trinavarat A, Pituksung A. Effective pupil dilatation with a mixture of $0.75 \%$ tropicamide and $2.5 \%$ phenylephrine: a randomized controlled trial. Indian J Ophthalmol. 2009;57(5):351-4.
9. Ong-Tone L, Bell A. Pupil size with and without adrenaline with diclofenac use before cataract surgery. J Cataract Refract Surg. 2009;35(8):1396-400.

10. Hirowatari T, Tokuda K, Kamei Y, Miyazaki Y, Matsubara M. [TPD ophthalmic solution (mixture of tropicamide, phenylephrine hydrochloride, and diclofenac sodium) for cataract surgery]. Nippon Ganka Gakkai Zasshi. 2002;106(10):630-3.

11. Ostrin LA, Glasser A. The effects of phenylephrine on pupil diameter and accommodation in rhesus monkeys. Invest Ophthalmol Vis Sci. 2004;45(1):215-21.

12. Tokuda K, Hirowatari T, Kamei Y, Miyazaki Y, Matsubara M. Availability of TPD ophthalmic solution (mixture of mydrin-P solution, neosynesin kowa solution, and diclod solution) in regard to the corneal barrier function--clinical evaluation for vitrectomy in patients with diabetic retinopathy]. Nippon Ganka Gakkai Zasshi. 2002;106(10):648-53.

13. Hossain MM, Mohiuddin AA, Hossain MA, Aziz MA. Diclofenac sodium and prednisolone acetate ophthalmic solution in controlling inflammation after cataract surgery. Mymensingh Med J. 2010;19(3):343-7.

14. Ratanapakorn T, Yospaiboon Y, Chaisrisawadsuk N. Single dose of $1 \%$ tropicamide and 10\% phenylephrine for pupil dilation. J Med Assoc Thai. 2006;89(11): 1934-9.

15. Evcim AS, Micili SC, Karaman M, Erbil G, Guneli E, Gidener S, dkk. The role of rac1 on carbachol-induced contractile activity in detrusor smooth muscle from streptozotocin-induced diabetic rats. Basic Clin Pharmacol Toxicol. 2015;116(6):47684.

16. Erken HA, Genc O, Erken G, Ayada C, Gundogdu G, Dogan H. Ozone partially prevents diabetic neuropathy in rats. Exp Clin Endocrinol Diabetes. 2015;123(2):1015.

17. Lee J, Lee HI, Seo KI, Cho HW, Kim MJ, Park EM, dkk. Effects of ursolic acid on glucose metabolism, the polyol pathway and dyslipidemia in non-obese type 2 diabetic mice. Indian J Exp Biol. 2014;52(7):683-91.

18. Aleo CL, Murchison AP, Dai Y,, Hark LA, Mayro EL, Collymore B, dkk. Improving eye care follow-up adherence in diabetic patients with ocular abnormalities: the effectiveness of patient contracts in a free, pharmacy-based eye screening. Public Health. 2015;129(7):996-9. 
Arief S. K.: Efektivitas Penambahan Natrium Diklofenak terhadap Larutan Obat Dilatasi Pupil pada Pasen Retinopati Diabetik

19. Mao X, Zhang S, Hen H, Du L, Li G, Li B, dkk. Corneal permeability assay of topical eye drop solutions in rabbits by MRI. J Huazhong Univ Sci Technolog Med Sci. 2010;30(6): 804-8.
20. Loftsson T, Stefansson E. Cyclodextrins in eye drop formulations: enhanced topical delivery of corticosteroids to the eye. Acta Ophthalmol Scand. 2002;80(2):144-50. 